\title{
Notes
}

\section{European Ophthalmic Pathology Society}

The European Ophthalmic Pathology Society held its 14th Annual Meeting in Oslo, Norway, 3-6 June, 1975. Dr J. A. C. Wadsworth, Durham, North Carolina, was the honoured guest. A further eight European guests and 32 members attended the meeting, which was organized by Professor and Mrs K. Arnesen. The scientific sessions were held at the University of Oslo, Institute of Preclinical Odontology, and a reception

\section{Ophthalmic Literature}

This journal, formerly published by the British Medical Association, is now (as from Vol. 29, September 1975) published by the Institute of Ophthalmology, University of London. It is believed that it is of value to ophthalmologists and it is therefore hoped that it will continue

\section{Courses, Symposia}

\section{Course in Microsurgery of the Eye}

\section{Nantes, March and October 1976}

The third and fourth courses on microsurgery of the eye will take place in Nantes. For further details write was given at the City Hall by the Mayor of Oslo. Dr S. Ry Andersen, Denmark, was elected President and Dr O. A. Jensen, Denmark, Corresponding Secretary. Dr A. S. Henriquez (Spain) and Dr D. Toussaint (Belgium) were elected new members. The next meeting will be a joint meeting with the Verhoeff Society in Washington, Dr L. E. Zimmerman will be the Organizing Secretary.

to prosper. Any profits will be devoted to ophthalmic research.

Inquiries should be addressed to the Circulation Manager, Ophthalmic Literature, Institute of Ophthalmology, Judd Street, London $\mathrm{WC}_{\mathrm{I}} \mathrm{H}_{9} \mathrm{QS}$.

\section{Intraocular Foreign Bodies and Metallosis}

\section{March to 2 April 1976}

The German Ophthalmological Society is sponsoring an international symposium. For further information to the Secretary, Course in Ocular Microsurgery, 16 Boulevard Gabriel Guist' hau, Nantes, 44000, France.

\section{Postgraduate Course in Ophthalmic Plastic Surgery \\ New York, 15 and 16 fanuary 1976}

The Page and William Black Postgraduate School of Medicine, Mount Sinai School of Medicine (CUNY), announces a postgraduate course in ophthalmic plastic surgery. For further details write to the Registrar, write to Professor Dr H. Neubauer, D-5000 Köln 4r, Universitäts-Augenklinik, Joseph-Stelzmann-Str. 9.

\section{Obituary}

\section{Stuart Harold Guise Humfrey MRCS(Eng), LRCP(Lond), BA, DOMS (1874-1975)}

Stuart Harold Guise Humfrey, formerly consultant ophthalmic surgeon to Northampton and Kettering hospitals, died on 9 June aged 81 years. Educated at Oakham and Caius College, Cambridge, and serving as an undergraduate in the Royal Field Artillery he continued his medical studies at St Thomas's Hospital. He was appointed assistant surgeon in 1926 and became the Page and William Black Postgraduate School of Medicine, Mount Sinai School of Medicine, Fifth Avenue and rooth Street, New York, NY roo29, USA. the senior consultant at Northampton in 1932 .

In his young days he was an outstanding sportsman, winning the schools' national championship in both high and long jump. He represented his county, Northamptonshire, at cricket, rugby, and golf. $\mathrm{He}$ is survived by his wife, son, and daughter and leaves behind many friends and patients who admired and loved him. 